\title{
CONTROLE DIFUSO NO NOVO CPC ${ }^{1}$
}

\section{DIFFUSE CONTROL IN THE NEW BRAZILIAN CIVIL PROCEDURE CODE}

Geovany Cardoso Jeveaux

Doutor em Direito pela Universidade Gama Filho (UGF/RJ). Mestre em Direito pela

Pontifícia Universidade Católica do Rio de Janeira (PUC/RJ). Professor Adjunto da Faculdade de Direito - Graduação e Programa de Pós-Graduação Stricto Sensu Mestrado da Universidade Federal do Espírito Santo (UFES). Juiz do Trabalho no Tribunal Regional do Trabalho da $17^{\text {a }}$ Região. E-mail: geovany.jeveaux@ hotmail.com

Hermes Zaneti Júnior

Pós-Doutor em Direito pela Università degli Studi di Torino. Doutor em Direito pela Universidade Federal do Rio Grande do Sul. Doutor em Direito pela Università degli Studi di Roma Tré. Mestre em Direito pela Universidade Federal do Rio Grande do Sul, Graduado em Ciências Jurídicas e Sociais pela Universidade do Vale do Rio dos Sinos. Professor da Graduação e Pós Graduação (Mestrado) da Universidade Federal do Espírito Santo (UFES). Promotor de Justiça no Estado do Espírito Santo. E-mail: hermeszanetijr@gmail.com

Recebido em: 12/11/2016 Aprovado em: 20/01/2017 Doi: $10.5585 /$ rdb.v16i7.563

RESUMO: O novo Código de Processo Civil (Lei $\left.n^{0} 13.105 / 2015\right)$ tratou de temas ligados ao controle difuso, em uma autêntica simbiose entre as matérias de direito processual e de direito constitucional, mas a aplicação prática do CPC/2015 nessa parte depende, principalmente, do domínio de alguns conceitos chave, sem os quais se pode antever dificuldades operatórias muito sérias. Neste trabalho, pretende-se realçar algumas dessas dificuldades (razoabilidade $v$. proporcionalidade; controle de convencionalidade; abstração do controle difuso $v$. inexigibilidade de título judicial; súmulas ordinárias vinculantes $v$. súmulas vinculantes) com a apresentação de vias interpretativas capazes de tornar as previsões legais mais adequadas, tanto na prática quanto na teoria.

Palavras-chave: Inconstitucionalidade; Controle difuso; Direito processual.

ABSTRACT: The new brazilian Civil Procedure Code (Act $\mathrm{n}^{\circ} 13.105 / 2015$ ) dealt with issues related to diffuse control in an authentic symbiosis between procedural law and constitutional law, but the practical application of the Code in this part depends on the domain of some key concepts (reasonability $v$. proportionality; conventionality control; abstraction of diffuse control $v$. ineligibility of judicial provision; ordinary binding "súmulas" $v$. binding "súmulas"), without which one can foresee very serious operative difficulties. In this work, we intend to highlight

\footnotetext{
${ }^{1}$ Este trabalho é fruto da pesquisa desenvolvida no Programa de Pós-Graduação Stricto Sensu em Direito Processual da UFES e no Grupo de Pesquisa "As Colisões de Direitos Fundamentais com Caráter de Princípio no NCPC", também da UFES, coordenado pelos autores deste texto em conjunto com Prof. Dr. Elias de Oliveira, do Departamento de Ciência da Computação (UFES).
}

Revista de Direito Brasileira | São Paulo, SP | v. 16 | n. 7 | p. 324 - 345 | Jan./Abr. 2017 
some of these difficulties, with the presentation of interpretative pathways able to make the most appropriate legal provisions, both in practice and in theory.

Keywords: Unconstitutionality; Diffuse control; Procedural law.

SUMÁRIO: Introdução; 1. Razoabilidade v. Proporcionalidade; 2. Controle de Convencionalidade; 3 . Abstrativização do Controle Difuso v. Inexigibilidade de Título Judicial; 4. Súmulas Ordinárias Vinculantes v. Súmulas Vinculantes; Conclusão; Referências Bibliográficas.

\section{INTRODUÇÃO}

Códigos são produto da tradição jurídica romano-germânica, surgidos no Estado representativo, que têm a pretensão de tratar de todos os aspectos da vida coletiva, no contexto da ideia de completude da ordem jurídica.

Tais diplomas legislativos têm ainda por característica a longevidade, não porque retratem as relações jurídicas entre as pessoas e destas com as coisas como se já estivessem dadas de uma vez por todas, mas porque têm a pretensão de retratar pro futuro o modo como a sociedade regulada aceita os institutos jurídicos do passado. Nesse sentido, as revogações de códigos são eventos incomuns e ocorrem apenas quando se reconhece haver um descompasso entre os institutos regulados e a tradição jurídica posterior dessa mesma sociedade.

O CPC de 1973 é um Código forjado para lides individuais e já se encontrava defasado em relação às lides coletivas, mas acabou também desatualizado no campo do direito constitucional, diante de alguns institutos surgidos na Constituição Federal de 1988 e em reformas constitucionais posteriores e de uma miríade de decisões tomadas pelo STF em sede de controle concentrado e difuso de constitucionalidade com forte carga discricionária, em um movimento em geral chamado (imprecisamente) de ativismo judicial. Tais inovações, reformas e decisões contribuíram para o sensível aumento da complexidade interpretativa do direito em geral e do direito processual em particular, mormente quando em jogo as lides de matriz constitucional.

O CPC de 2015 aparece assim no cenário jurídico nacional como meio de atualizar o direito processual brasileiro a uma nova realidade, mas nesse propósito parece ter olvidado o debate prévio amadurecido em torno dos pontos de contato com o direito constitucional, que serão abordados neste trabalho.

Apenas para exemplificar, essa carência de diálogo ocorreu também com a teoria do direito, bastando registrar aqui a tão curiosa quanto imprecisa referência a valores fundamentais estabelecidos na Constituição Federal para a ordenação, disciplina e interpretação do Código em seu art. $1^{\circ}$. Afinal, em qual quadro teórico os "valores" da dignidade humana, da não discriminação e da prevalência dos direitos humanos, encontrados no art. $1^{\circ}$ da Constituição Federal, podem ou devem orientar a ordenação, disciplina e interpretação do CPC? Não se trata de uma indagação retórica, porque ao se mencionar a proporcionalidade no art. $8^{\circ}$ como um dos critérios de solução da colisão entre "normas", citada no $\S 2^{\circ}$ do art. 489 , o art. $1^{\circ}$ poderia sugerir a adesão a uma teoria dos valores para orientar tal solução, oposta assim uma teoria deontológica. Trata-se de problema teórico sério, de grande profundidade e extensão, com severas implicações práticas, porque em matéria de colisão entre direitos fundamentais cada uma dessas teorias parte de premissas diferentes que em geral levam a resultados distintos.

No caso da primeira teoria, teria de haver um parâmetro valorativo prévio capaz de medir os interesses em jogo, o que resultaria invariavelmente em uma escala hierárquica a partir da qual o resultado do embate estaria sempre predeterminado.

Já em uma teoria deontológica dogmática, na tradição da jurisprudência dos conceitos, como a de Robert Alexy, a ponderação entre direitos fundamentais com caráter de princípio como critério de solução de colisões não aceita uma definição prévia ou a priori antes do cotejo 
concreto entre os direitos.

Conforme Alexy, entrando em colisão os princípios, a solução do embate exige que se faça uma ponderação entre eles, conforme a dimensão do peso. Isso porque, não havendo hierarquia, relação de tempo pregresso ou exceção entre os princípios, diferentemente do que ocorre com as regras, a escolha entre um deles não se faz por uma relação de prioridade incondicionada. Daí a necessidade de uma "lei de colisão".

Grosso modo, a "lei de colisão" diz que a precedência depende das consequências jurídicas dos princípios, sendo, pois, um pressuposto fático do princípio precedente, ou por outra, que os princípios não têm relação absoluta de precedência e não são quantificáveis. Logo, a dimensão do peso é apenas uma metáfora, já que não é possível quantificar os interesses em colisão de forma abstrata ou absoluta, mas apenas de forma concreta e relativa. Essa lei de colisão se relaciona com outra, chamada por Alexy de lei de ponderação, que resume a máxima da proporcionalidade.

Enquanto a lei de colisão diz que não é possível encontrar uma decisão previamente dada para o embate entre princípios, e que a decisão será encontrada em regras que definem certas condições fáticas, que, uma vez ocorrentes, indicam as consequências jurídicas de precedência de um princípio sobre outro, a primeira lei de ponderação procurar explicar racionalmente o grau de importância das consequências jurídicas de ambos os princípios em colisão.

Em outras palavras, a lei de ponderação, na eventualidade da colisão não ter sido solucionada pelas máximas parciais anteriores (adequação e necessidade), coloca as consequências jurídicas dos princípios ainda em colisão numa balança (metáfora do peso), a fim de precisar qual delas é racionalmente mais importante naquele caso concreto.

As referências a valores e à proporcionalidade acima feitas são pertinentes ao controle de constitucionalidade.

Isso ocorre porque no primeiro caso o parâmetro valorativo constitucional apenas orienta a aplicação das regras processuais como valores em relação às demais regras processuais infraconstitucionais, mas ao contrário, quando considerado em seu aspecto deontológico, constrange como norma, uma vez que o caráter deontológico e supraordenado que a própria Constituição assume em relação a todo ordenamento jurídico faz com que as normas processuais infraconstitucionais somente se considerem válidas se de acordo com as normas constitucionais, tanto no aspecto formal como substancial.

Segundo, quanto à proporcionalidade, porque se põem em confronto dois ou mais direitos fundamentais, fora, portanto dos critérios de conflito de regras (hierarquia, especialidade e anterioridade) ou mais especificamente da relação de regularidade (matéria também pertinente à deontologia). Essas observações foram feitas porque há uma linha de contato do segundo tema com a razoabilidade (conceitos que serão explorados a seguir) e mormente para confirmar a hipótese inicial acerca da falta de diálogo ou carência de diálogo suficiente e prévio entre processualistas e constitucionalistas no campo do controle difuso.

\section{RAZOABILIDADE $v$. PROPORCIONALIDADE}

De acordo com o art. $8^{\circ}$ do NCPC, “ao aplicar o ordenamento jurídico, o juiz...” deverá observar a proporcionalidade e a razoabilidade, além de outros axiomas normalmente chamados de princípios (legalidade, publicidade e eficiência).

No direito constitucional, proporcionalidade e razoabilidade possuem duas abordagens temáticas diferentes, a saber: 1) a europeia, na qual a razoabilidade/racionalidade e a proporcionalidade foram reunidas em três etapas da máxima ${ }^{2}$ da proporcionalidade (adequação,

2 A proporcionalidade é um axioma, e não um princípio, porque é usada para resolver a colisão entre direitos Revista de Direito Brasileira | São Paulo, SP | v. 16 | n. 7 | p. 324 - 345 | Jan./Abr. 2017 
necessidade e proporcionalidade em sentido estrito) ${ }^{3}$; 2) a americana, na qual se faz o exame separado da means-end relationship e do test of balancing.

A primeira delas tem em Robert Alexy o principal expoente ${ }^{4}$, para quem os direitos fundamentais têm caráter de princípio, que provém do mandado típico dos enunciados/disposições das normas de direitos fundamentais (baixa densidade normativa). Como os princípios podem entrar em colisão, esse caráter de princípio implica na máxima da proporcionalidade, com as suas três máximas parciais: 1) adequação; 2) necessidade ou idoneidade do meio (meio mais benigno); 3) proporcionalidade em sentido estrito (ponderação). Logo, do mandado contido nos enunciados/disposições das normas de direitos fundamentais se deduz o caráter de princípio dos direitos fundamentais, e desse caráter se deduz a máxima da proporcionalidade, como critério de solução de eventual colisão entre princípios de direitos fundamentais 5 . As máximas parciais, por sua vez, "definem o que deve entender-se por' otimização, de acordo com a teoria dos princípios" $"$.

As possibilidades fáticas que condicionam a precedência entre os princípios em colisão são encontradas nas máximas da adequação e da necessidade, enquanto que as possibilidades jurídicas são encontradas na máxima da proporcionalidade em sentido estrito ${ }^{7}$. Analisadas em conjunto, essas possibilidades são determinantes para a solução da colisão no caso concreto. A solução representada pela lei de colisão formará uma regra, que, para ser racional, deverá ser universalizável. ${ }^{8}$

A primeira máxima parcial da máxima da proporcionalidade exige que o meio usado para atingir o fim de um princípio de direito fundamental seja adequado, no sentido de uma relação entre meios-e-fins, ou seja, no sentido de não haver um desvio de finalidade de um princípio pelo mal uso do meio empregado em sua prática. Assim, se um decreto de

fundamentais com caráter de princípio, e por isso ela mesma nunca entra em colisão com um direito fundamental com caráter de princípio (ALEXY, Robert. Teoria de los Derechos Fundamentales, p. 112 - nota 84). Humberto Ávila denomina este axioma de postulado normativo aplicativo (ÁVILA, Humberto. Teoria dos Princípios. Da Definição à Aplicação dos Princípios Jurídicos. São Paulo: Malheiros, 2005).

3 Cf. CANAS, Vitalino. O Princípio da Proibição do Excesso na Constituição: arqueologia e aplicações. In: MIRANDA, Jorge (org.). Perspectivas Constitucionais. Nos 20 Anos da Constituição de 1976. Coimbra: Coimbra Editora, 1997, V. II, p. 323-358; e SANDULLI, Aldo. Ecesso di Potere e Controllo di Proporzionalità. Profili Comparati. Rivista Trimestrale di Diritto Publico, Roma: Giuffrè Editore, 1995, p. 329-370.

${ }^{4}$ Vários autores trataram desse tema subjacente, ao distinguirem princípios de regras, mas Alexy foi o único a apresentar uma teoria dogmática, capaz de auxiliar a solução prática das colisões entre direitos fundamentais, para as quais os critérios de solução dos conflitos de regras não são adequados. A principal teoria concorrente à de Alexy é a de Dworkin, mas ela não tem caráter dogmático e sua matiz moral (direito como integridade política) não é satisfatória para a explicitação prática de colisões entre direitos fundamentais, diante da dificuldade em se obter consenso sobre qual decisão é a mais compatível com a razão pública e de não permitir, ao mesmo tempo, o controle intersubjetivo das razões (razões, que, diga-se de passagem, a teoria não exige sejam explicitadas e justificadas). No Brasil, a teoria de Alexy é criticada na perspectiva analítica por Humberto Ávila (Teoria dos Princípios, passim) e na perspectiva hermenêutica por Lenio Streck e a escola hermenêutica gaúcha (STRECK, Lenio. Verdade e consenso: Constituição, hermenêutica e teorias discursivas. $5^{\text {a }}$ ed., revista, modificada e ampliada. São Paulo: Saraiva, 2014, principalmente p. 221-251; OLIVEIRA, Rafael Tomaz de. Decisão judicial e o conceito de princípio: $a$ hermenêutica e a (in)determinação do direito. Porto Alegre: Livraria do Advogado, 2008). Para um estudo crítico da visão de Humberto Ávila a partir da insuficiência de critérios dogmáticos seguros para a solução daquele tipo de embate, capazes de substituir satisfatoriamente a teoria de Alexy, cf. op. cit., p. 121-124, nota de rodapé n. 91.

${ }^{5}$ Idem, p. 111.

${ }^{6}$ ALEXY, Robert. Epílogo a la Teoría de los Derechos Fundamentales. Revista Española de Derecho Constitucional. Madrid: Centro de Estudios Políticos y Constitucionales, n. 66, set/dez 2002, p. 26, "definen lo que debe entenderse por optimización, de acordo con la teoría de los principios".

${ }^{7}$ Idem, p. 112-113.

${ }^{8}$ A formação de uma regra a partir da colisão resulta em um reforço da teoria dos precedentes e no atingimento de uma das premissas do positivismo jurídico que é a exigência de uma regra para o caso que tenha caráter universalizável, para a melhor explicitação destas ideias, inclusive com um atento diálogo as críticas de Luigi Ferrajoli ao proposto por Robert Alexy, cf. ZANETI JR., Hermes. $O$ valor vinculante dos precedentes, p. 226-242.

Revista de Direito Brasileira | São Paulo, SP | v. 16 | n. 7 | p. 324 - 345 | Jan./Abr. 2017 
desapropriação, a pretexto de atender ao princípio do interesse público, é utilizado para punir um adversário político ou para impedir um negócio legítimo de compra-e-venda apenas porque tal negócio é contrário às opções ideológicas da autoridade pública, o meio utilizado para atingir o fim daquele princípio enunciado não foi adequado. Se, entre dois princípios em colisão, o meio empregado para a realização de um deles, já no exame da primeira máxima, se mostrar inadequado, o outro princípio prevalece. Caso contrário, ou seja, se os meios de realização de ambos os princípios forem igualmente adequados, continua-se a pesquisa com a máxima seguinte.

A segunda máxima parcial é a da necessidade, que exige indagar previamente se havia mais de um meio adequado de realização do fim de cada princípio em colisão. Se os meios de realização dos princípios opostos eram únicos, ambos foram necessários. Caso contrário, deve-se investigar se o meio eleito entre os meios possíveis era o mais benéfico ou o menos maléfico. Ou seja, de acordo com Alexy, "o meio não é necessário se se dispõe de um mais suave ou menos restritivo", de tal modo que "o fim não pode ser obtido de outra maneira que afete menos o indivíduo", conforme já decidiu o Tribunal Constitucional alemão ${ }^{10}$. Desse modo, se o meio eleito era o necessário para ambos os princípios, ou seja, o menos gravoso, a colisão continua. Caso contrário, a colisão se resolve em favor do princípio de meio mais necessário.

Permanecendo a colisão, quando ambos os meios são adequados e necessários, exsurge então a terceira máxima parcial da proporcionalidade, ou seja, a proporcionalidade em sentido estrito, pela qual se cumpre um mandado de ponderação, também enunciado como lei de ponderação.

Referida lei pode ser assim definida, de acordo com Alexy: 1) "quanto maior é o grau da não satisfação ou de afetação de um princípio, tanto maior tem que ser a importância da satisfação do outro"; ou 2) "quanto mais intensa se revelar a intervenção em um dado direito fundamental, maiores hão de se revelar os fundamentos justificadores dessa intervenção" 11 . Em outras palavras, a primeira lei de ponderação "diz o que é o importante nas ponderações, quer dizer, o grau ou a intensidade da não satisfação de um princípio, por um lado, e o grau de importância da satisfação do outro princípio, por outro", ou seja, "diz o que é que tem de ser fundamentado racionalmente", já que "a lei de ponderação enquanto tal não formula nenhuma pauta com cuja ajuda possam ser decididos definitivamente os casos". Daí a sua relação com a lei de colisão.

Enquanto a lei de colisão diz que não é possível encontrar uma decisão previamente dada para o embate entre princípios, e que a decisão será encontrada em regras que definem certas condições fáticas e jurídicas, que, uma vez ocorrentes, indicam as consequências jurídicas de precedência de um princípio sobre outro, a lei de ponderação procurar explicar racionalmente o grau de importância das consequências jurídicas de ambos os princípios em colisão. Em outras palavras, a lei de ponderação, na eventualidade de o embate não ter sido solucionado pelas máximas parciais anteriores, coloca as consequências jurídicas dos princípios ainda em colisão numa balança (metáfora do peso), a fim de precisar qual delas é racionalmente mais importante naquele caso concreto. Nas palavras de Alexy, "a ponderação não é um procedimento no qual um bem é obtido com excessiva pressa a custo de outro [...] seu resultado é um enunciado de preferência condicionado que, de acordo com a lei de colisão, surge de uma regra diferenciada de

\footnotetext{
9 ALEXY, Robert. Colisão e Ponderação como Problema Fundamental da Dogmática dos Direitos Fundamentais. Palestra proferida na Casa de Rui Barbosa, em 10.12.1998. Tradução de Gilmar Ferreira Mendes, p. 10.

10 Op. cit., p. 114 (BverfGE 38, 281 (302)). ("el fin no puede ser logrado de otra manera que afecte menos al individuo").

11 ALEXY, Robert. Colisão e Ponderação como Problema Fundamental da Dogmática dos Direitos Fundamentais. Palestra proferida na Casa de Rui Barbosa, em 10.12.1998. Tradução de Gilmar Ferreira Mendes, p. 10. 
decisão". 12

Por isso, "a lei de ponderação aponta, primeiro, para a importância da satisfação do princípio oposto e formula, segundo, um mandado"13, vale dizer, uma regra como resultado da própria decisão, regra essa que transforma o direito prima facie do princípio precedente em direito definitivo, mantendo o direito contido no princípio precedido em seu estado prima facie ou relativo.

Tal operação deve ser realizada em três etapas, a saber: $1^{\text {a }}$ ) define-se a intensidade da intervenção, ou seja, o grau de insatisfação ou afetação de um dos princípios; 2a) define-se a importância dos fundamentos justificadores da intervenção, isto é, a importância da satisfação do princípio oposto; $3^{\text {a }}$ ) realiza-se a ponderação em sentido estrito, ou seja, responde-se sobre se a importância da satisfação de um princípio justifica a não satisfação do outro princípio ${ }^{14}$. De forma simplificada, pode-se conceber essas etapas como o resultado de uma relação entre prós e contras ou de custos e benefícios, na qual se pondera se os prós ou benefícios são proporcionalmente maiores do que os contras ou custos, de tal modo que o princípio com menor custo para o outro seja o preferível.

A segunda abordagem é encontrada no direito constitucional norte-americano, principalmente nos casos em que a lei confere tratamento desigual entre as pessoas ${ }^{15}$, quando então se exige que a classificação diferencial seja razoável e racional. De acordo com Carlos Roberto de Siqueira Castro:

[...] isto requer dizer que a norma classificatória não deve ser arbitrária, implausível ou caprichosa, devendo, ao revés, operar como meio idôneo, hábil e necessário ao atingimento de finalidades constitucionalmente válidas. Para tanto, há de existir uma indispensável relação de congruência entre a classificação em si e o fim a que ela se destina. Se tal relação de identidade entre meios e fins 'means-end-relationship', segundo a nomenclatura norte-americana - da norma classificatória não se fizer presente, de modo que a distinção jurídica resulte leviana e injustificada, padecerá ela do vício da arbitrariedade, consistente na falta de 'razoabilidade' e de 'racionalidade', vez que nem mesmo ao legislador legítimo, como mandatário da soberania popular, é dado discriminar

\footnotetext{
${ }^{12}$ ALEXY, Robert. Colisão e Ponderação como Problema Fundamental da Dogmática dos Direitos Fundamentais. Palestra proferida na Casa de Rui Barbosa, em 10.12.1998. Tradução de Gilmar Ferreira Mendes, p. 10.

${ }^{13}$ Op. cit., p. 161-162, 164 e 166-167. ("Cuanto mayor es el grado de la no satisfacción o de afectación de un principio, tanto mayor tiene que ser la importancia de la satisfacción del otro"); (“dice qué es lo importante en las ponderaciones, es decir, el grado o la intensidad de la no satisfacción de un principio, por un lado, y el grado de importancia de la satisfacción del otro principio, por el otro"); (“dice qué es lo que tiene que ser fundamentado racionalmente"); ("la ley de la ponderación en tanto tal no formula ninguna pauta con cuya ayuda pudieran ser decididos definitivamente los casos"); (".la ponderación no es un procedimiento en el cual un bien es obtenido con'excesivo apresuramientó a costa de otro [...] su resultado es un enunciado de preferencia condicionado que, de acuerdo con la ley de colisión, surge de un regla diferenciada de decisión"); ("la ley de ponderación apunta, primero, a la importancia de la satisfacción del principio opuesto y formula, segundo, un mandato"). É de se questionar se o espaço para a justificação externa das premissas adotadas, assim como o resultado e seu controle subjetivo, necessários para o terceiro passo - tipicamente jurídico - da ponderação não seja exatamente a conexão entre a teoria de Alexy e a hermenêutica filosófica. Isto ocorre justamente porque a soundness - a coerência ou, querendo, a integridade - dependem da compreensão do ordenamento jurídico. Defendendo essa ordem de ideias e a aproximação entre Alexy e Dworkin no ponto em questão cf. ZANETI JR., Hermes; PEREIRA, Carlos Frederico Bastos. Teoria da Decisão Judicial no Código de Processo Civil: Uma ponte entre Hermenêutica e Analítica?, Revista de Processo, n. 259, ano 41, p. 21-53. São Paulo: RT, 2016.

${ }_{14}^{14}$ Palestra cit., p. 10; e art. cit., p. 32.

${ }^{15}$ Também se costuma referir ao modo como as leis são editadas, porque aonde o lobby é institucionalizado e os projetos de lei são submetidos a hearings, ocasião em que os interesses em jogo são debatidos, o produto legislativo pode ser conferido como base nesses debates prévios, de modo que uma lei que preveja tratamento estranho à matéria antes debatida pode ser acusada de violar a relação de meios e fins, revelando-se assim como um ato arbitrário e, portanto, irrazoável e irracional.
}

Revista de Direito Brasileira | São Paulo, SP | v. 16 | n. 7 | p. 324 - 345 | Jan./Abr. 2017 
injustificadamente entre pessoas, bens e interesses na sociedade política ${ }^{16}$.

Se o meio empregado não atingir o fim desejado pelo dispositivo constitucional, a autoridade que o editou terá exorbitado de sua competência, praticando um ato de abuso de poder, e como todo o sistema constitucional se encontra construído com o objetivo de evitar tal abuso, segue-se que tal meio será inconstitucional.

Logo, o propósito do princípio da razoabilidade e da racionalidade no direito americano é o de fornecer um critério para o controle de constitucionalidade, diferentemente da máxima da proporcionalidade para os europeus, que serve principalmente para solucionar colisões entre direitos fundamentais com caráter de princípio e secundariamente para revelar falsas colisões entre direitos fundamentais, quando o embate termina na primeira ou na segunda etapa, hipótese em que somente então o caso se revela como de controle de constitucionalidade ou de legalidade.

Os americanos resolvem o problema da colisão entre direitos fundamentais por intermédio do test of balancing ${ }^{17}$, que é um:

[...] princípio básico de justiça do sistema de pesagem entre dois lados da uma mesma questão. Exame de prós e contras. O objetivo fundamental é o de encontrar a eqüidade ou a imparcialidade (como equilíbrio perfeito). Constitucionalmente, o princípio envolve direitos individuais garantidos pela Constituição ponderados diante de direitos estatais, em áreas como as da proteção da igualdade e de liberdade de expressão e de imprensa ${ }^{18}$.

Como se percebe, o tema não é autoevidente e tampouco abre concessão à facilidade, sendo que o art. $8^{\circ}$ do CPC de 2015 em nada auxilia o intérprete sobre qual vertente seguir (quanto à teoria, a redação do $\S 2^{\circ}$ do art. 489 seguiu claramente a de Robert Alexy), sugerindo apenas que ao separar as expressões proporcionalidade e razoabilidade se estaria seguindo a abordagem americana.

O grande problema dessa vertente é que ela pressupõe um altíssimo grau de certeza sobre qual tipo de embate está em disputa, demonstrando, porém a experiência que um caso inicialmente tratado como uma colisão entre direitos fundamentais pode se revelar um controle de constitucionalidade ou de legalidade e vice versa.

Por exemplo: em épocas de infestação de mosquitos transmissores da dengue (e hoje da zica e da chikungunya) algumas autoridades estaduais e municipais editam decretos autorizando que seus agentes de saúde requisitem força policial para adentrar as residências fechadas e naquelas nas quais os moradores não atendem ou se recusam a abri-las para as inspeções, numa aparente colisão entre os direitos fundamentais da incolumidade pública e da inviolabilidade da residência, mas quando se constata que há uma reserva de jurisdição para flexibilizar esse segundo direito (inc. XI do art. $5^{\circ}$ da $\mathrm{CF} / 88$ ) a colisão é imediatamente barrada na etapa da adequação, porque um decreto não é adequado para substituir uma ordem judicial, caso em que se afasta a colisão e se reconhece a inconstitucionalidade daquele ato normativo.

Exemplo inverso: um vizinho demanda uma igreja evangélica que instala autofalantes do lado de fora para obter adesão de novos fiéis, reclamando que o som é alto e que professa outra religião, vindo a se verificar depois que o som não fere os limites do art. 42 do DL 3688/41, mas

16 CASTRO, Carlos Roberto de Siqueira. O Devido Processo Legal e a Razoabilidade das Leis na Nova Constituição do Brasil. Rio de Janeiro: Forense, 1989, p. 157.

${ }^{17}$ GARCÍA, Enrique Alonso. La Interpretacion de la Constitucion. Madrid: Centro de Estudios Constitucionales, 1984, p. 413 e ss.

18 GIFIS, Steven H. Law Dictionary. New York: Barrońs, 2003, p. 44: "principle basic to the justice system of weighing both sides of an issue. Examining the pros and cons. The ultimate goal is to seek equality or evenhandedness (a perfect balance). Constitutionally, it involves individual rights guaranteed by the Constitution weighed against state rights in such areas as equal protection and freedom of speech and press". 
que a profissão de fé é exposta de forma ofensiva a outras religiões, hipóteses em que se nega o controle de legalidade da atitude da igreja e que se constata a existência de colisão entre o mesmo direito fundamental (livre expressão religiosa), a ser resolvida pelas etapas da proporcionalidade.

Com isso, conclui-se o seguinte: 1) a separação nominal da proporcionalidade e da razoabilidade, no art. $8^{\circ}$ do $\mathrm{CPC} / 2015$, indica que em linha de princípio o direito brasileiro seguiu a vertente americana, mas tal separação não pode ser tomada de forma absoluta, porque a experiência mostra que um caso inicialmente tratado como uma colisão entre direitos fundamentais pode se revelar um controle de constitucionalidade ou de legalidade e vice versa, de modo que apenas quando há um alto grau de certeza ${ }^{19}$ sobre o tipo de embate que está em disputa é que se deve partir de uma ou de outra abordagem, esta opção cabe ao intérprete e é controlada a partir do caso concreto e da tradição jurídica; 2) constatando-se que um caso inicialmente tratado como de colisão entres direitos fundamentais reclama controle de constitucionalidade ou vice versa, a vertente inicial (proporcionalidade $v$. razoabilidade) deve ser convertida na outra para a solução coerente da questão discutida, assegurando-se previamente o contraditório de ambas as partes (art. 10 do CPC/2015), mediante conversão do julgamento em diligência; 3) sendo o caso de incidência da proporcionalidade, deve-se aplicar a teoria de Alexy, já que o $\S 2^{\circ}$ do art. 489 do $\mathrm{CPC} / 2015$ citou expressamente os conceitos ligados às leis de colisão e de ponderação, respectivamente, seguindo-se a rotina da adequação, da necessidade e da proporcionalidade em sentido estrito. $^{20}$

\section{CONTROLE DE CONVENCIONALIDADE}

Nos termos do art. 13 do CPC, "a jurisdição civil será regida pelas normas processuais brasileiras, ressalvadas as disposições específicas previstas em tratados, convenções ou acordos internacionais de que o Brasil seja parte".

Tal redação informa que disposições processuais contidas em documentos normativos internacionais excepcionarão o CPC caso tenham previsões divergentes, restando saber se a exceção ocorrerá no contexto do critério de generalidade/especialidade ou no do critério hierárquico do conflito entre regras. A rigor, a exceção sugere o primeiro critério, porque nesse tipo de conflito de regras uma não elimina a outra, limitando-se a excepcioná-la, no pressuposto de que uma regra especial derroga a geral apenas nos casos especialmente tratados. Por outro lado, não se pode ignorar que na edição da SV n. 25 o STF acabou tratando incidentalmente do segundo critério, deixando assentado, em resumo, que 1) tratados/convenções internacionais que versem sobre direitos humanos terão hierarquia constitucional somente quando aprovados pelo mesmo procedimento e quorum das emendas constitucionais, sendo que 2) aqueles de mesmo conteúdo não aprovados daquela forma terão status supralegal. Logo, 3) tratados/convenções internacionais que não versem sobre direitos humanos continuam tendo status legal, revogando e

\footnotetext{
${ }^{19}$ Uma solução simplificada seria adotar sempre a vertente europeia, mas nos casos em que não se duvida do controle de constitucionalidade ou de legalidade nunca haverá mais de um meio a ponderar sequer sobre a licitude dos meios (adequação) e sobre a existência de outro meio menos gravoso (necessidade), porque haverá tão somente um meio em exame: o ato normativo questionado diante de um parâmetro constitucional ou legal.

${ }^{20} \mathrm{Na}$ doutrina, criticando essa posição e afirmando que o CPC no art. 489, $\S 2^{\circ}$ é inconstitucional por ofensa ao art. 93, X da CF/88 uma vez que não se ponderam regras e o CPC fala em ponderação de "normas", incluindo ai as regras, conferir STRECK, Lenio. Art. 489. In.: STRECK, Lenio; NUNES, Dierle; CUNHA, Leonardo Carneiro da (orgs.). Comentários ao Código de Processo Civil. São Paulo: Saraiva, 2016, p. 688-690. Contudo, nos parece que essa critica não deve subsistir, para afastá-la: a) basta interpretar o termo norma como apenas normas-princípio, conferindo interpretação conforme; b) quando estivermos diante da colisão entre um princípio e uma regra contraposta, basta aplicar também as noções de caráter prima facie das regras (observância de sua prevalência em face do princípio democrático e do processo legislativo) e de ponderação de regras a partir de seus princípios fundantes. Isso porque, após a superação do seu caráter prima facie das regras é possível a ponderação entre o princípio contraposto e o princípio que está na base da regra.
}

Revista de Direito Brasileira | São Paulo, SP | v. 16 | n. 7 | p. 324 - 345 | Jan./Abr. 2017 
sendo revogados por leis ordinárias e complementares, de acordo com o critério temporal de resolução de conflito de regras (later in time rule $)^{21}$.

De fora parte o paradoxo latente que há nesse entendimento, já que na segunda hipótese se abrigam documentos materialmente constitucionais que não têm hierarquia formalmente constitucional, e por isso não são parâmetro de controle de constitucionalidade, mas de controle de convencionalidade ${ }^{22}$, o fato é que essa nova categoria normativa pode também afetar a aplicação do CPC, embora por outro critério de solução do conflito entre regras.

Novamente, tais conceitos não são vazios, porque 1) uma coisa é deixar-se de aplicar o CPC diante de algum tratado/convenção internacional (de que o Brasil seja aderente, por óbvio) com ele conflitante no pressuposto de que se põem em confronto uma regra geral e uma regra especial, e 2) outra bem diferente é deixar-se de aplicá-lo no pressuposto de que seja hierarquicamente inferior a algum tratado/convenção internacional, quer por ser constitucional ou quer por ser supra-legal, ou 3) de que sejam da mesma hierarquia mas tenham tempos de edição distintos. No primeiro critério, qualquer tratado/convenção internacional que verse sobre regras processuais será aplicado em lugar do $\mathrm{CPC}$, seja qual for o seu conteúdo (direitos humanos ou não) e seja qual for o tempo de sua aprovação, afirmando-se a especialidade. No segundo critério, tudo depende do conteúdo versado (necessariamente direitos humanos) e do procedimento de aprovação (de emendas constitucionais ou não), afirmando-se o critério da hierarquia. Já no último, o que importa é o tempo de edição e que a mesma matéria processual tratada não abrigue direitos humanos, caso em que apenas os tratados/convenções internacionais posteriores ao CPC teriam incidência, anterioridade.

Considerando que nem todas as matérias processuais versam ou abrigam direitos humanos ou fundamentais, a última hipótese supra praticamente negaria o propósito do art. 13 do CPC e de várias outras disposições que seguem a mesma linha (p. ex.: arts. $24,83, \S 1^{\circ}, \mathrm{I}, 1033$, $\left.1035, \S 3^{\mathrm{o}}, \mathrm{III}^{23}\right)$, já que haveria uma seleção temporal entre tratados/convenções internacionais de conteúdo comum aprovados antes e depois do Código, seleção essa que não se compraz com o texto daquele dispositivo.

Assim, deve-se concluir que o art. 13 do NCPC adotou o critério da generalidade/especialidade para resolução do conflito de suas regras com as regras processuais de tratados/convenções internacionais aprovados pelo Brasil, mas isso não exclui o critério hierárquico contido no julgamento da SV n. 25, vale dizer, a regra do art. 13 do CPC diz respeito aos tratados/convenções internacionais que versem sobre direitos processuais comuns, seja qual for o tempo de sua aprovação pelo Brasil, mas quando tais documentos internacionais dispuserem sobre direitos processuais de índole fundamental seus enunciados ou dispositivos (no controle textual) e suas normas (no controle interpretativo) servirão de parâmetro para controle das regras conflitantes do CPC nos casos concretos em exame, seja porque o documento internacional goza de status constitucional (controle de constitucionalidade), seja porque goza de status supralegal (controle de convencionalidade).

Vale uma última observação. O CPC repetiu em diversos artigos normas constitucionais (p. ex.: arts. $\left.3^{\circ}, 11,176\right)$. Nestes casos apenas os tratados aprovados com status de emenda constitucional deverão prevalecer sobre as normas do CPC, preservando-se o critério hierárquico. Enquanto não alterado o texto constitucional, por força do art. $1^{\circ}$ do $\mathrm{CPC}$ e da superioridade hierárquica a norma clonada no CPC prevalece sobre o tratado.

\footnotetext{
${ }^{21}$ Cf. JEVEAUX, Geovany Cardoso; PEPINO, Elsa. Comentários às Súmulas Vinculantes. Com pesquisa sobre a regra do art. 52, $X$, da CF. Rio de Janeiro: GZ, 2012, p. 153-168.

${ }^{22}$ Todo controle exige um parâmetro, que é um dispositivo/enunciado (controle textual) ou uma norma (controle interpretativo) presente em um texto superior, comparado a um objeto, que é um dispositivo/enunciado (controle textual) ou uma norma (controle interpretativo) presente em um texto inferior.

${ }^{23} \mathrm{O} \S 3^{\circ}$ do art. 26 foge dessa lógica, porque nele a cooperação jurídica internacional, a ser prevista em tratado próprio, não poderá contrariar "as normas fundamentais que regem o Estado brasileiro".
}

Revista de Direito Brasileira | São Paulo, SP | v. 16 | n. 7 | p. 324 - 345 | Jan./Abr. 2017 


\section{ABSTRATIVIZAÇÃO DO CONTROLE DIFUSO $v$. INEXIGIBILIDADE DE TÍTULO JUDICIAL}

$\mathrm{O} \S 12$ do art. 525 e o $\S 5^{\circ}$ do art. 535 do CPC/2015 dispõem que a sentença condenatória de cumprimento de obrigação de pagar quantia certa, proferida em face dos devedores em geral e da Fazenda Pública em particular, respectivamente, pode ser objeto de impugnação quando o fundamento jurídico do título houver sido proclamado inconstitucional pelo STF em sede de controle concentrado e também de controle difuso. No primeiro tipo de controle essa matéria também é comumente chamada de inconstitucionalidade da coisa julgada, enquanto que no segundo tipo ela tem sido tratada com o nome de abstrativização do controle difuso, para designar os casos em que ele supostamente recebe a mesma eficácia erga omnes do controle concentrado. O grande problema, aqui, é que nos casos em que o STF se ocupou desse segundo tema ele próprio não estabeleceu um quadro teórico coerente para tratá-lo.

Em algumas decisões, o STF passou a admitir o emprego no controle difuso da modulação de efeitos prevista no art. 27 da Lei 9868/99 para o modelo concentrado e também uma eficácia transcendente (ao interesse das partes do litígio concreto e à própria decisão), soluções que excepcionam a regra geral da eficácia limitada às partes e que merecem exame dos fundamentos respectivos.

O primeiro desses casos paradigmáticos foi o do RE n. 197.917-8, cujo julgamento teve início em 31.08.1999 e fim em 24.03.2004, com publicação do Acórdão em 07.05.2004.

O objeto sob controle era o art. $6^{\circ}$ da Lei Orgânica do Município paulista de Mira Estrela, acusado de malferir o parâmetro do art. 29, IV, "a", da CF, no qual se exige uma relação de proporcionalidade entre o número de vereadores e o número de habitantes por município. $\mathrm{O}$ Município em questão possuía 2.651 (dois mil, seiscentos e cinquenta e um) habitantes para 11 (onze) vereadores, quando em uma proporcionalidade aritmética devia ter apenas 9 (nove) vereadores. Por isso, entendeu o Ministro Relator, Maurício Corrêa, que o objeto sob controle era inconstitucional, ponderando, contudo que,

[...] a despeito de a legislatura a que se refere a decisão de primeiro grau - quadriênio 1993/97 - já ter se exaurido, o presente recurso não se acha prejudicado. Com efeito, a ação promovida pelo Parquet questionou a composição da Câmara Legislativa do Município por entendê-la contrária à Carta da República, em face do excesso de representantes. Tal situação persiste, porquanto os eleitores de Mira Estrela elegeram para o quadriênio 2001/2004 o mesmo quantitativo de 11 (onze) Vereadores. Remanesce, portanto, o interesse em reduzir esse número e a consequente declaração incidental de inconstitucionalidade da norma municipal.

Por isso, além da declaração de inconstitucionalidade, na conclusão do voto foi determinado "à Câmara Legislativa que, após o trânsito em julgado, adote as medidas cabíveis para adequar sua composição aos parâmetros ora fixados".

A tese da inconstitucionalidade foi vencedora, pelo voto da maioria os Ministros, mas os argumentos do Ministro Gilmar Mendes sobre a eficácia do julgamento são os que mais interessam à matéria em exame.

Em seu voto, referido Ministro assim se manifestou acerca da eficácia do julgado: 1) em caso de alegada inconstitucionalidade de lei eleitoral, aconselha-se que o Tribunal não proclame tal status quando o reconhecimento da nulidade não for capaz de resolver o problema e em lugar da pronúncia seja capaz de encontrar uma norma apta a preencher eventual lacuna no 
ordenamento; 2) em outras palavras, exige-se a "necessidade de um outro princípio que justifique a não aplicação do princípio da nulidade", axioma que tem aplicação indistinta tanto ao controle concentrado quanto ao controle difuso, como mostra a experiência americana, na qual o controle é exclusivamente difuso e concreto, mas admite a restrição dos efeitos retroativos da pronúncia de inconstitucionalidade desde o caso Linkletter $v$. Walter $(1965)^{24}$, com base em critérios de política legislativa $^{25}$; 3 ) já no modelo alemão, no qual o controle é concentrado, a restrição dos efeitos retroativos da pronúncia de inconstitucionalidade é admitida desde o caso do regime de execução penal (Strafgefangene), de $1972^{26}$, com base em critério estritamente constitucional; 4) no direito pátrio prevalece ainda o princípio da nulidade da lei ou ato normativo inconstitucional, mas ele deve ser excepcionado "nos casos em que se revelar absolutamente inidôneo para a finalidade perseguida (casos de omissão; exclusão de benefício incompatível com o princípio da igualdade), bem como nas hipóteses em que a sua aplicação pudesse trazer danos para o próprio sistema jurídico constitucional (grave ameaça à segurança jurídica)"; 5) "assim, configurado eventual conflito entre o princípio da nulidade e o princípio da segurança jurídica, que, entre nós, tem status constitucional, a solução da questão há de ser, igualmente, levada a efeito em um processo de complexa ponderação"; 6) no Brasil se deve supor que a pronúncia de inconstitucionalidade não afeta todos os atos singulares praticados com base na lei assim proclamada, precisamente em nome do princípio da segurança jurídica, cabendo aqui a distinção "entre o efeito da decisão no plano normativo (Normebene) e no plano do ato singular (Einzelaktebene)"; 7) a regra do art. 27 da Lei 9868/99, que confere ao STF discricionariedade na fixação dos limites temporais da pronúncia de inconstitucionalidade no controle concentrado e abstrato, permite que se pondere, com vista em razões de segurança jurídica, se "a supressão da norma poderá ser mais danosa para o sistema do que a sua preservação", de modo semelhante à decisão de apelo ao legislador do direito alemão ${ }^{27}$, devendo ser aplicada também ao controle difuso e concreto, com base no mesmo juízo de ponderação; 8) os modelos mais próximos do direito nacional são o português e o alemão, porque também aqui "a não-aplicação do princípio da nulidade não se há de basear em consideração de política judiciária, mas em fundamento constitucional próprio"; 9) no caso em comento, eventual decisão retroativa atingiria atos da Câmara Municipal praticados tanto antes (fixação do número de vereadores, fixação do número de candidatos e definição do quociente eleitoral) quanto depois do pleito (validade das deliberações da edilidade nos projetos e lei aprovados), de modo que "um juízo rigoroso de

\footnotetext{
${ }^{24}$ Nesse caso foi negado ao impetrante de habeas corpus a mesma interpretação antes reconhecida no caso Mapp v. Ohio (1961), no sentido da inadmissão de provas obtidas por meio ilícito, porque, embora tivesse ocorrido o mesmo em seu caso concreto, a condenação ocorrera perante uma corte estadual e o trânsito em julgado antes da decisão da Suprema Corte.

${ }^{25}$ Em específico, a justificativa foi o problema que tal extensão generalizada traria para a administração da justiça. O argumento usado para tanto foi retórico: "A Constituição nem proíbe nem exige efeito retroativo". Existe porém outra hipótese em que a restrição de efeitos é recomendada: quando há mudança de jurisprudência, ocasião em que a nova decisão passa a valer pro futuro (prospective overruling). "Em alguns casos, a nova regra afirmada para decisão aplica-se aos processos pendentes (limited prospectivity); em outros, a eficácia ex tunc exclui-se de forma absoluta (pure prospectivity). Embora tenham surgido no contexto das alterações jurisprudenciais de precedentes, as prospectivity têm integral aplicação às hipóteses de mudança de orientação que leve à declaração de inconstitucionalidade de uma lei antes considerada constitucional".

${ }^{26}$ Nesse caso, algumas restrições gerais relativas à execução da pena, antes consideradas constitucionais porque implícitas à condição dos condenados (como a intercepção de correspondência), foram reconhecidas como inconstitucionais, admitindo-se todavia a sua manutenção até que o legislador alterasse a lei. No entendimento da Corte Constitucional, "a Lei Fundamental, enquanto ordenação objetiva de valores com ampla proteção dos direitos fundamentais, não pode admitir uma restrição ipso jure da proteção dos direitos fundamentais para determinados grupos de pessoas".

27 Em outras palavras, “o princípio da nulidade somente há de ser afastado se se puder demonstrar, com base numa ponderação concreta, que a declaração de inconstitucionalidade ortodoxa envolveria o sacrifício da segurança jurídica ou de outro valor constitucional materializável sob a forma de interesse social".
}

Revista de Direito Brasileira | São Paulo, SP | v. 16 | n. 7 | p. 324 - 345 | Jan./Abr. 2017 
proporcionalidade recomenda a preservação do modelo legal existente na atual legislatura", "cabendo ao legislativo municipal estabelecer nova disciplina sobre a matéria, em tempo hábil para que se regule o próximo pleito eleitoral (declaração de inconstitucionalidade pro futuro)".

No final dos debates, o Ministro Nelson Jobim advertiu que o entendimento vencedor devia ser submetido ao Tribunal Superior Eleitoral, comprometendo-se então o Ministro Sepúlveda Pertence a fazê-lo, com o objetivo de "dar uma orientação uniforme a esse respeito para todo o País", naquilo que o Ministro Gilmar Mendes chamou de efeito transcendente.

Como se observa, o STF não conferiu uma eficácia erga omnes autônoma à decisão no controle difuso, recomendando, porém (i) a modulação de efeitos pro futuro, mediante ponderação entre a preservação da segurança jurídica dos atos praticados com base no dispositivo questionado em sua constitucionalidade e a sua retirada do ordenamento com base no princípio da "nulidade", e (ii) a possível extensão do resultado a terceiros, inclusive para os fins de atingir competência normativa alheia (no caso, o TSE), que deveria observar o entendimento do tribunal.

E assim ocorreu: o Ministério Público Eleitoral apresentou Representação junto ao TSE, para que garantisse a unidade do direito a parti da decisão acima relatada, e aquele Tribunal editou a Res. n. 21.702/2004, que foi objeto por sua vez das ADIs ns. 3345 e 3365 (esta última teve os autos apensados à primeira), julgadas improcedentes no pressuposto da constitucionalidade não apenas do poder normativo primário do TSE, como também pelo fato de apenas haver replicado a interpretação do STF, na qualidade de intérprete máximo da CF, dando concreção ao princípio da força normativa da constituição.

O Ministro Relator daquelas ADIs, Celso de Mello, chamou o efeito transcendente de efeito irradiante e atribuiu seu tratamento anterior ao julgamento da Reclamação n. $1987^{28}$, que tinha por objeto alegado descumprimento pelo TRT-10 do julgamento contido na ADI n. 1662, em cuja razão de decidir consta que o sequestro previsto no art. 100 da CF somente é admitido em caso de violação da ordem de pagamento (seja de créditos alimentares ou comuns), e não quando há falta de inclusão do débito no orçamento ou pagamento inidôneo (a menor ou fora do prazo). $\mathrm{O}$ ato normativo objeto daquela ADI era a IN n. 11/97 do TST, que após o deferimento de medida liminar foi substituída pelo Provimento n. 03/98, adequado aos termos daquela decisão interlocutória. Sobreveio então a EMC n. 30, alterando o regime dos precatórios, e quando do julgamento definitivo da ADI o STF entendeu que as mudanças contidas naquela Emenda não alteravam a ratio decidendi contida na medida liminar. A polêmica, então, passou a ser o cabimento da Reclamação quando o seu objeto devia ser supostamente outro (um ato normativo do TST, e não uma decisão do TRT-10), razão pela qual o tema da eficácia transcendente foi suscitado. $O$ efeito transcendente teria então conotação não apenas objetiva, focada na interpretação do dispositivo controlado, como também subjetiva, já que a decisão poderia alcançar entes diversos daquele que editou o ato sob controle, como bem lembrou o Ministro Sepúlveda Pertence ao criticar o exame dessa matéria em sede de Reclamação: "então, quando julgarmos da constitucionalidade ou não de uma lei estadual, os outros Estados que tenham leis similares virão aqui, não com uma ação direta, mas com uma reclamação".

De fora parte a polêmica sobre o cabimento da Reclamação naquela hipótese, o tema da eficácia transcendente somente foi tratado em pormenor no voto do Ministro Gilmar Ferreira Mendes, assim resumido: 1) o efeito vinculante das ações de controle concentrado alcança não apenas a parte dispositiva do Acórdão, como também suas razões ou seus fundamentos

\footnotetext{
${ }^{28}$ No mesmo voto o Ministro Relator cita a medida liminar deferida pelo Ministro Relator Gilmar Ferreira Mendes nos autos da Reclamação n. 2126, datada de 19.08.2002, na qual consta que a "eficácia da decisão do Tribunal transcende o caso singular, de modo que os princípios dimanados da parte dispositiva e dos fundamentos determinantes sobre a interpretação da Constituição devem ser observados por todos os Tribunais e autoridades nos casos futuros". Contudo, em 01.02.2008 o Reclamante pediu desistência e referido incidente não chegou a ser julgado no mérito, de modo que não pode servir de parâmetro para a uniformização da matéria junto ao STF, coisa que somente se alcançou na Reclamação n. 1987.
}

Revista de Direito Brasileira | São Paulo, SP | v. 16 | n. 7 | p. 324 - 345 | Jan./Abr. 2017 
determinantes, porque a sua concepção na PEC que resultou na EMC n. 3/93 está desde sempre vinculada ao modelo previsto no $\S 31$ da Lei Orgânica da Corte Constitucional alemã; 2) no modelo alemão, oscilou-se entre o extremo que abrange inclusive os obter dicta e aquele que nega tal extensão para além da coisa julgada tradicional para por fim se aceitar orientações mediadoras, como a proposta por Klaus Vogel, para quem a coisa julgada alcança também a "norma decisória concreta", correspondente à "ideia jurídica subjacente à formulação contida na parte dispositiva, que, concebida de forma geral, permite não só a decisão do caso concreto, mas também a decisão de casos semelhantes"; 3) o próprio STF já estaria a aplicar tal eficácia no controle difuso de leis municipais, ao estender a um RE as razões de decidir tomadas anteriormente em outro RE a propósito de outras leis municipais de conteúdo semelhante (REs ns. 228.844, 221.795, 364.160, 423.252, 345.048 e 384.521); 4) "tal procedimento evidencia, ainda que de forma tímida, o efeito vinculante dos fundamentos determinantes da decisão exarada pela Corte Constitucional".

A Ementa do Acórdão de referida Reclamação incluiu a solução apresentada pelo Ministro Gilmar Mendes, mas algumas observações devem ser feitas a seu respeito: 1) entre os extremos teóricos acima citados, o conceito de "norma decisória concreta" parece parar nos limites da ratio decidendi, portanto sem incluir os obter dicta; 2) há um sério problema conceitual envolvido nas expressões efeito vinculante e efeito transcendente, porque elas não expressam a mesma coisa: efeito vinculante significa a vedação de decisões em sentido contrário, enquanto que efeito transcendente significa o transporte ${ }^{29}$ das razões de decidir de uma decisão para outra ação, outro recurso ou outro ato normativo (como ocorreu com a Res. TSE n. 21.702/2004); 3) logo, quando se trata de sujeitar outros sujeitos passivos diversos daqueles que editaram o ato sob controle a uma determinada decisão, está-se falando em eficácia vinculante, e quando se trata de estender uma decisão a outro processo com pano de fundo semelhante, está-se falando em eficácia transcendente; 4) com isso, os exemplos do controle difuso de leis municipais se enquadram no segundo conceito, enquanto que a extensão subjetiva da ADI n. 1662 se insere no primeiro; 5) portanto, não é propriamente a natureza do controle que é determinante da distinção entre tais conceitos, e sim a sua ontologia.

O parêntese da Reclamação n. 1987-0 esclarece melhor agora o voto do Ministro Gilmar Ferreira Mendes nos autos das ADIs ns. 3345 e 3365.

Depois de voltar aos exemplos de eficácia transcendente (que também chamou de vinculante) em sede de controle difuso de leis municipais, inclusive para dispensar a intervenção do Senado, pela via do art. 52, $\mathrm{X}$, da $\mathrm{CF}^{30}$, referido Ministro citou ainda os seguintes fundamentos para seu entendimento: 1) tal eficácia teria como fundamento também o caput do art. 557 do CPC (art. 932, III, do NCPC), já que as Turmas tem "considerado dispensável, no caso de modelos legais idênticos, a submissão da questão ao Plenário"; 2) no controle por via de ações coletivas (ação civil pública e mandado de segurança coletivo) a eficácia erga omnes da decisão que se acha nelas possibilitada também dispensa a intervenção do Senado e inclusive pode prejudicar ADI posterior (ADI n. 1919) ${ }^{31}$; 3) a parte final do parágrafo único do art. 949, I e II, do CPC, atual, dispensa os tribunais inferiores de submeter a questão constitucional ao pleno ou ao órgão especial (art. 97 da CF) quando a matéria já houver sido examinada pelo STF em

\footnotetext{
${ }^{29}$ Expressão tomada de empréstimo do transporte da coisa julgada coletiva in utilibus (e secundum eventum litis) prevista no $\S 3^{\circ}$ do art. 103 do $\mathrm{CDC}$, para os casos de condenação coletiva com posterior liquidação individual. No caso em exame, porém, o transporte não se faz do campo coletivo para o campo individual, mas de uma decisão para outra.

30 Providência que havia sido considerada desnecessária nos debates finais do julgamento do RE n. 197.917-8 por motivos óbvios, já que a suspensão de lei municipal já teria sido superada pela invalidade declarada na própria decisão do STF.

31 A ADI em questão foi considerada prejudicada porque seu objeto (Res. n. 556/97, do Conselho Superior da Magistratura Paulista) já havia sido fulminado em sede de mandado de segurança coletiva pelo STJ.
}

Revista de Direito Brasileira | São Paulo, SP | v. 16 | n. 7 | p. 324 - 345 | Jan./Abr. 2017 
sede de controle difuso; 4) os modelos de controle têm a mesma natureza, o que explica os efeitos gerais ou transcendentes também no controle difuso; 5) a modulação de efeitos do art. 27 da Lei n. 9868/99 é uma técnica de harmonização do modelo misto brasileiro, especialmente nos casos de mudança de jurisprudência.

Também aqui são necessárias algumas observações, a saber: 1) as hipóteses do parágrafo único do art. 949 do CPC/2015 e do caput do art. 932, III, do CPC/2015 são precedentes, não há mais necessidade de se falar em eficácia transcendente ou irradiante por força do art. 927, caput, e incisos do $\mathrm{CPC}$, especialmente no inciso V, pois as decisões de controle de constitucionalidade difuso, quando afirmam a inconstitucionalidade, são sempre pelo pleno do Tribunal. Assim, por força do stare decisis (art. 926, caput e art. 927, $\S \S 2^{\circ}, 3^{\circ}$ e $4^{\circ}$, especialmente) e da eficácia vinculante as decisões anteriores do STF em sede de controle difuso estas devem ser transportadas para decisões de órgãos fracionários dos tribunais inferiores e para as turmas do próprio STF, respectivamente, sem a necessidade de decisão do órgão especial ou do pleno que as confirme. Por força do CPC essa eficácia é propriamente vinculante, mas o órgão especial ou o pleno pode examinar a matéria, seja para confirmar a decisão anterior, seja para excepcioná-la em caso de distinguish, quando a distinção for suscitada pela parte; 2) no caso das ações coletivas em que há controle de constitucionalidade incidental existem duas facetas: a) a dispensa de intervenção posterior do Senado (especificamente nas ações civis públicas contra leis e atos normativos municipais) não implica em transporte das razões de decidir, precisamente porque a intervenção é considerada redundante, não havendo assim qualquer decisão posterior para a qual o resultado seja conduzido; b) a prejudicialidade potencial de futura ADI depende não apenas do status do órgão julgador na estrutura judiciária, como também do resultado da demanda, mas de alguma forma há também o transporte das razões de decidir sobre a decisão extintiva da ADI, já que se pode antever o seu resultado coincidente (no caso da ADI n. 1919 a extinção acabou por referendar a decisão do STJ) ou prejudicial (como ocorreu com a ADI n. 4071-5, adiante analisada), uma vez que a força do precedente firmado pelo próprio tribunal também o vincula no caso, stare decisis; 3) novamente, a identidade ontológica entre os modelos de controle difuso e concentrado explica não apenas a distinção entre efeitos transcendentes (agora, a força dos precedentes para os casos futuros) e efeitos vinculantes (para a retirada do ordenamento jurídico da norma impugnada), como também justifica a modulação de efeitos.

$\mathrm{Na}$ ordem cronológica (invertida acima com o exame das ADIs ns. 3345 e 3365 e da Reclamação n. 1987-0, em sequência do RE n. 197.917-8), o segundo paradigma foi o julgamento do HC n. 82.959-7 (publicado em 01.09.2006), que depois serviu de leading case para a Súmula Vinculante n. $26^{32}$, que tem a seguinte redação:

Para efeito de progressão de regime no cumprimento de pena por crime hediondo, ou equiparado, o juízo da execução observará a inconstitucionalidade do art. $2^{\circ}$ da Lei n. 8072, de 25 de julho de 1990, sem prejuízo de avaliar se o condenado preenche, ou não, os requisitos objetivos e subjetivos do benefício, podendo determinar, para tal fim, de modo fundamentado, a realização de exame criminológico.

O texto supra resume o resultado do julgamento, no qual a tese da inconstitucionalidade foi vencedora por maioria, tendo o Ministro Gilmar Mendes repetido a parte do voto do paradigma anterior acerca da modulação de efeitos no controle difuso e concluído que se devia conferir eficácia ex nunc à pronúncia de inconstitucionalidade do $\S 1^{\circ}$ do art. $2^{\circ}$ da Lei 8072/90, entendendo-se "como aplicável às condenações que envolvam situações ainda suscetíveis de serem submetidas ao regime de progressão".

\footnotetext{
32 A respeito, JEVEAUX, Geovany Cardoso; PEPINO, Elsa Maria Lopes Seco Ferreira. Comentários às Súmulas Vinculantes. Com pesquisa sobre a regra do art. 52, X, da CF. Op. cit., pp. 169-181.
}

Revista de Direito Brasileira | São Paulo, SP | v. 16 | n. 7 | p. 324 - 345 | Jan./Abr. 2017 
No voto seguinte, da Ministra Ellen Gracie, seguiu-se uma crítica à modulação de efeitos, em especial acerca do caráter pro futuro (pure prospectivity), porque nessa hipótese a solução sequer seria aplicável ao paciente do habeas corpus em julgamento, deixando de ter utilidade para o caso concreto. Tampouco seria hipótese de efeitos limitados ao paciente (limited prospectivity), por conta de um obstáculo lógico:

Se as sentenças já publicadas ficam resguardadas da nova interpretação, pelo bom motivo de que os juízes que as proferiram não poderiam prever que a jurisprudência assente da Casa - e tantos anos após a promulgação da nova Constituição - se fosse reverter dessa sorte, como excetuar dessa salvaguarda a sentença condenatória no caso presente? O juiz que prolatou, tanto quanto o TJSP, encontrava-se na mesma situação fática de insciência ou imprevisibilidade de todos os seus demais colegas.

Em resumo, "a Corte estaria se avocando um arbítrio excessivo ao selecionar quais réus serão beneficiados retroativamente por seu novo entendimento".

Essa última parte do voto provocou um interessante debate no qual o Ministro Gilmar Mendes revelou a preocupação que o levou a propor a eficácia retroativa para o caso concreto em julgamento e a eficácia prospectiva para os demais casos semelhantes. Em suas palavras, ao se reconhecer a inconstitucionalidade de uma lei que era antes declarada constitucional, "vamos ter de fazer uma série de perguntas, inclusive, em matéria penal, como por exemplo, a responsabilidade civil do Estado e tudo mais". Trocando em miúdos, também no modelo brasileiro essa modulação de efeitos no controle difuso, em específico quanto à matéria penal, leva em conta razões de ordem política, e não estritamente de ordem constitucional. Afinal, como bem apontou o Ministro Sepúlveda Pertence, "essa declaração, na verdade, equivale à introdução de uma lei penal mais benéfica e, esta, até por imperativo constitucional, teria de aplicar-se". A essa observação o Ministro Gilmar Mendes opôs o seguinte: "não posso supor que o Estado vá agora responder pela prisão, se se considera que era constitucional à época", no que foi jocosamente retrucado pelo Ministro Sepúlveda pertence: "haveria, primeiro, ação regressiva contra o Brossard e o Resek".

Apesar desse elegante sarcasmo ${ }^{33}$, o que mais preocupa, em termos argumentativos, não é a justificativa da modulação de efeitos no controle concreto, que em tese é mesmo possível, na linha de exposição do Ministro Gilmar Mendes, mas sim a opção por um modelo supostamente imunizado de razões políticas de decidir, quando as razões estritamente constitucionais de decidir não são assim tão imunes a questões de política judiciária ou econômica.

O tema foi novamente tratado no voto do Ministro Nelson Jobim (Presidente), que assim se manifestou:

[...] é certo que, historicamente, o Supremo Tribunal Federal já, diversas vezes, modulou, no controle difuso, à vista da circunstância ou do caso concreto ou da equação jurídica do caso concreto, os seus efeitos. Lembro a mais recente e expressiva delas: a do cancelamento da Súmula 394, quando se estabeleceu, por decisão unânime do Plenário, que a nova orientação seria inaplicável aos

\footnotetext{
${ }^{33}$ Falando sério mais adiante, e ainda a propósito do mesmo assunto, registrou o Ministro Sepúlveda Pertence a seguinte advertência acerca da modulação proposta pelo Ministro Gilmar Mendes para o caso em julgamento e especialmente para os demais semelhantes: "não se está impondo ao juízo das execuções que abra as portas indistintamente: há de examinar caso a caso a ocorrência dos pressupostos da progressão, abstraída apenas a vedação legal que se declara inconstitucional". Depois, em seu voto, renovou a advertência: "isso não impedirá que o condenado, que esteja, ainda, a cumprir a sua pena, postule a progressão de regime". Vale lembrar que no debate acima relatado a eficácia prospectiva para os demais casos semelhantes se aplicaria pelo restante da pena a cumprir. De acordo com o Ministro Gilmar Mendes, "se houver ainda um dia de pena, teremos a progressão".
} 
processos findos. E, também, o caso dos vereadores no qual, em nome da segurança das regras do jogo eleitoral, não se quis cortar, além da metade, o mandato que fora disputado para número de vagas que o Tribunal depois entendeu exagerado.

No fim do julgamento a matéria voltou à tona, com o Ministro Gilmar Mendes renovando sua preocupação com a real causa da modulação dos efeitos, ou seja, a potencial responsabilidade civil do Estado por erro judicial ou prisão excessiva, fazendo então o Ministro Sepúlveda Pertence duas propostas: 1) deixar "claro que a decisão não se aplica a eventuais consequências jurídicas às penas extintas"; 2) que a decisão fosse comunicada ao Senado, decerto para os fins do art. $52, \mathrm{X}$, da $\mathrm{CF} / 88$. Essa última proposta daria à decisão um caráter erga omnes $\mathrm{e}$ pro futuro, com a retirada da norma do ordenamento jurídico, mas essa já era a proposta do Ministro Gilmar Mendes, e que acabou depois generalizada no julgamento da Reclamação n. 4335-5, na qual o STF passou a atribuir ao Senado uma função meramente formal de publicação da decisão do tribunal acerca da inconstitucionalidade, reservando à própria decisão o efeito erga omnes.

Em resumo, no voto do Ministro Gilmar Mendes a decisão em si mesma teria eficácia erga omnes para "condenações que envolvam situações ainda suscetíveis de serem submetidas ao regime de progressão", mas para o Ministro Sepúlveda Pertence tal generalização dependia da suspensão do dispositivo inconstitucional pelo Senado. Seja como for, a edição de Súmula Vinculante acabou por dar eficácia erga omnes e vinculante à matéria, já que nenhum juízo criminal pode decidir em sentido contrário após a sua publicação. ${ }^{34}$

Como se percebe, no primeiro (RE n. 197.917-8) e no segundo (HC n. 82.959-7) paradigmas as decisões reclamaram um complemento decisório para se generalizar, o que permite concluir que a eficácia transcendente acabou se reduzindo à eficácia erga omnes, ou ainda, que a primeira não possui autonomia para produzir simultaneamente a segunda. Este problema reduz, mas não se elimina, com o CPC, por força da vinculatividade das decisões do Pleno do STF em matéria constitucional (art. 927, V).

O último paradigma é o julgamento do Agravo Regimental de decisão terminativa do Ministro Relator Menezes Direito tomada na ADI n. 4071-5, na qual o processo foi extinto sumariamente sem a resolução do mérito, com base no art. $4^{\circ}$ da Lei n. 9868/99, no pressuposto de que o objeto impugnado (art. 56 da Lei n. 9430/96) já havia sido proclamado constitucional em sede de dois recursos extraordinários (REs 377.457 e 381.964) e de que não se apresentavam novos argumentos relevantes ou mudança de ordem jurídica, social ou econômica suficientes para justificar a mudança de entendimento anterior, antevendo-se com isso a manifesta improcedência do pedido.

Com efeito, dispõe o art. $4^{\circ}$ da Lei n. $9868 / 99$ que a petição inicial de ADI pode ser indeferida quando "manifestamente improcedente", de modo que a questão que devia ter sido resolvida era a da possibilidade de dois julgamentos anteriores tomados em sede de controle difuso, em sentido contrário à tese contida na ADI, serem capazes de indicar a sua manifesta improcedência. Contudo, o STF não se ocupou dessa matéria e gastou todo o julgamento decidindo em questão de ordem sobre o limite temporal de ingresso de amicus curiae em sede de ADI, fixando finalmente o entendimento de que ele coincide com a data imediatamente anterior à da liberação do processo para a pauta pelo Relator. Com isso, somente se pode deduzir que a maioria seguiu a mesma interpretação do Relator, ao indeferir a petição inicial da ADI, inclusive

\footnotetext{
${ }^{34}$ A questão das súmulas será tratada adiante. Contudo, é bom salientar desde logo que o CPC prevê o atrelamento das súmulas, como extratos dos precedentes, às circunstâncias fáticas e aos precedentes que lhes deram origem. Há, portanto, uma concreção dos enunciados da súmula que não havia antes e que dependerá da convergência com os fundamentos determinantes - considerados assim o conjunto das circunstâncias fáticas e da solução jurídica - dos precedentes que lhes deram origem (art. 926, $\S 2^{\circ}$ ).
}

Revista de Direito Brasileira | São Paulo, SP | v. 16 | n. 7 | p. 324 - 345 | Jan./Abr. 2017 
quanto a sua ressalva.

Contrario sensu, pode-se também deduzir que o contrário possa acontecer com ADCs cuja tese tenha sido refutada em sede de REs julgados anteriormente, agora com base no art. 15 da Lei n. 9868/99, que contém idêntica previsão do art. $4^{\circ}$ para as ADIs.

Para o que interessa ao tema em estudo, o caso foi de atribuição de eficácia vinculante por carona do efeito dúplice da improcedência da ADI e também transcendente aos julgados dos REs, não, porém sobre relações jurídicas materiais idênticas àquelas da ratio decidendi, mas sobre ADIs e ADC futuras, numa espécie de simbiose entre os modelos difuso e concentrado. AS circunstâncias fáticas dos recursos extraordinários foram abstraídas para se considerar como circunstância fática relevante o texto legal impugnado, a lei como fato, sendo a partir da sua análise em confronto com a Constituição identificada a inconstitucionalidade, que representa a solução jurídica: daí segue-se a aplicação do fundamento determinante do recurso julgado ao juízo de admissibilidade da ADI.

De tudo isso é possível concluir teoricamente que: 1) a eficácia vinculante significa a proibição de decisões em sentido contrário àquele da ratio decidendi estabelecida em sede de controle concentrado ou difuso, devendo ser atualizados os precedentes do STF a partir do advento do $\mathrm{CPC} / 2015 ; 2$ ) a tendência anterior do STF era de não tratar ambos como similares, tanto assim que nos dois primeiros paradigmas acerca da matéria examinada houve a necessidade de um ou mais complementos decisórios capazes de gerar efeitos vinculantes, a saber: a) no RE 197.917-8, o julgamento das ADIs ns. 3345 e 3365 no sentido da constitucionalidade da Res. TSE n. 21.702/2004, que produziu o resultado de uma ADC procedente (efeito dúplice), proibitivo de decisões em sentido contrário; b) no HC n. 82.959-7, a Súmula Vinculante n. 26, contudo não há mais esta necessidade em face da nova norma infraconstitucional que atribui aos juízes e tribunais a obrigatoriedade de seguir as decisões do plenário; ${ }^{35} 3$ ) a eficácia transcendente ou irradiante expressa o transporte das razões de decidir de uma decisão para outra ação, outro recurso ou outro ato normativo (como ocorreu com a Res. TSE n. 21.702/2004), ou seja, trata-se de estender uma decisão a outro processo com pano de fundo semelhante, e não de sujeitar outros sujeitos passivos diversos daqueles que editaram o ato sob controle a uma determinada decisão (eficácia vinculante) é agora substituída pela força vinculante dos precedentes do STF; 4) a modulação de efeitos prevista no art. 27 da Lei n. 9868/99 para o controle concentrado tem perfeito cabimento no controle difuso, tanto pela identidade ontológica entre tais modelos, como também porque em vários casos concretos se exige um cálculo de proporcionalidade entre a preservação da segurança jurídica dos atos praticados com base no dispositivo questionado em sua constitucionalidade e a sua retirada do ordenamento com base no princípio da "nulidade".36

\footnotetext{
${ }^{35}$ A esdrúxula estrutura anterior permitia que apenas os juízes do tribunal de apelação fossem vinculados as decisões do STF em controle difuso, enquanto juízes de primeiro grau e o próprio STF não deviam obediência aos precedentes firmados em matéria constitucional pelo Pleno. Mauro Cappelletti já criticara fortemente a existência do controle difuso sem o stare decisis: "levaria à consequência de que uma mesma lei ou disposição de lei poderia não ser aplicada, porque julgada inconstitucional, por alguns juízes, enquanto poderia, ao invés, ser aplicada, porque não julgada em contraste com a Constituição, por outros" CAPPELLETTI, Mauro. Il controlo giudiziario di costituzionalità delle leggi nel diritto comparato [1968], trad. para o português de Aroldo Plínio gonçalves, CAPPELLETTI, Mauro. O controle de constitucionalidade de leis no direito comparado. trad. Aroldo Plínio Gonçalves; revisão José Carlos Barbosa Moreira. Porto Alegre: Sergio Antonio Fabris Editor, 1992, p. 77, conferir p. 76 e ss., $\S \S 4^{\circ}$ e $5^{\circ}$. No mesmo sentido: MARINONI, Luiz Guilherme. Precedentes obrigatórios. $4^{\mathrm{a}}$ ed. São Paulo RT, 2016, p. 75 ss;

${ }^{36}$ Chegando a conclusões teóricas próximas, afirmando, contudo a distinção entre a eficácia vinculante e o efeito transcendente, e a inconstitucionalidade dos arts. 525, $\S 12$ e 13 do CPC para os direitos difusos, conferir a pesquisa realizada junto à UFES no ano de 2015 (Com as seguintes participações: Geovany Cardoso Jeveaux (coordenador), Tainá Aguiar Junquilho (mestranda bolsista), Camila Pirovani Paixão, Kenedy Adans Roeldes Dally (graduandos bolsistas), Raphael de Angelo Jogaib Bomfim, Jordan Tomazelli Lemos, João Pedro Sarmento Dias Turíbio (graduandos participantes) e Aline Simonelli (participante externa). que tinha como hipóteses a serem confirmadas ou rejeitadas (i) a falta de estabelecimento pelo STF de um quadro teórico seguro para a aplicação das eficácias

Revista de Direito Brasileira | São Paulo, SP | v. 16 | n. 7 | p. 324 - 345 | Jan./Abr. 2017
} 
transcendente/irradiante e erga omnes no controle difuso e (ii) a falta de eficácia vinculante das decisões paradigma. Constatado que: 1) no último julgamento paradigmático a eficácia transcendente se deu do controle difuso (REs 377.457 e 381.964) para o controle concentrado pro futuro, a sua aplicação a casos concretos de controle difuso ficou evidentemente prejudicada; 2) o primeiro julgamento paradigmático foi sucedido de ato normativo erga omnes (Resoluções TSE ns. 21.702/2004 e 22.810/2008), por sua vez sucedido por expediente com eficácia vinculante autônoma (SV n. 26), o mesmo ocorrendo com o segundo julgamento paradigmático (ADIs 3345 e 3365 ), foi necessário delimitar os períodos de pesquisa de casos concretos julgados pelo STF e outros tribunais nos quais aquelas eficácias podiam ter sido efetivamente aplicadas. Assim, a pesquisa acabou confinada aos dois primeiros julgamentos paradigmáticos, dentro dos seguintes períodos, respectivamente: 1) 24.03.2004 (data de julgamento do RE 197.917) a 02.04.2004 (data de edição da Res. TSE n. 21.702); 2) 23.02.2006 (data do julgamento do HC 82.959) e 16.12.2009 (data de edição da SV n. 26). No primeiro desses períodos foram localizados 7 (sete) REs (199.522, 266.994, 273.844, 274.048, 274.384, 276.546 e 300.343), julgados em conjunto pelo STF no dia 31.03.2004, nos quais o voto vencedor do Ministro Relator, Maurício Corrêa, mencionou expressamente a aplicação da tese contida no julgamento do RE 197.917, por conta de sua identidade com a matéria dos casos então examinados. A decisão não foi unânime, mas a vitória da maioria implicou em eficácia transcendente/irradiante da decisão paradigmática para os casos pendentes, mais por conta da identidade da matéria do que propriamente por força de uma predeterminação vinculante. Em vários outros casos, julgados principalmente após o prazo acima citado, tanto pelo STF quanto por outro tribunais (por amostragem), a aplicação dos termos da decisão paradigmática do STF ocorreu com base (i) em argumentos apenas persuasivos, como, por exemplo, a segurança jurídica e o princípio da colegialidade, (ii) ou por simples remissão a ela: 1) pelo próprio STF: RE 282606 SP, AI 310616, RE 403590, AI 465238, RE 276406, RE 281504, RE 264204, RE 264468, RE 214110, RE 352569 (decisão monocrática); 2) pelo TJSC: AC 80732 SC 2003.0080732, AC 41497 SC 2004.0041497, AC 161740 SC 2003.0161740, AC 254390 SC 2003.0254390, AC 65078 SC 2004.006507-8, AC 75910 SC 2004.0075910, AC 119135 SC 2004.0119135, AC 126573 SC 2004.0126573, AC 64974 SC 2003.0064974, AC 288775 SC 2003.0288775, ADI 95004 SC 2003.0095004; 3) TJSP: APL 9044882-60.2001.8.26.0000; 4) TJRS: APL 70013937685. Em outros, a decisão do RE 197.917 foi usada apenas como reforço legitimador da Res. TSE n. 21.702/2004, tanto pelo TSE quanto por outros tribunais (por amostragem): 1) pelo TSE: RMS 363, RMS 347, RMS 375, RMS 360, RMS 392, RMS 350, RMS 373, RMS 344; 2) pelo TJPR: AI 1541262, AI 1506836, AI 1561626, AI 1532352, AI 1540976, AI 1567657, AI 1573240, AI 1596298, AI 1660491, ACP 1644866, ACP 1665927, AI 2622980; 3) pelo TJRS: ADI 70008511891; 4) pelo TJSC: ADI 72724 SC 2004.007272-4; 5) pelo TJMG: MS 2004.014924-9; 6) pelo TRE-MG: Recurso Eleitoral 905 - Acórdão 1.899/2008, Recurso Eleitoral 909 - Acórdão 1.916/2008; 7) pelo TJSP: MS 2685, Apelação em ACP 994.03.079597-2 (356.950.5/5-00), Apelação Cível 0003415-24.2009.8.26.0471, ADI 960934520118260000 SP 0096093-45.2011.8.26.0000; 8) pelo TRE-CE: Recurso Contra Diplomação 11079; 8) pelo TRE-SP: Recurso Eleitoral 32754 - Acórdão 167929; 9) pelo TJRJ: ADI 81 RJ 2000.007.00081. Também de forma persuasiva em relação ao julgamento do RE 197.917, porém com base na força vinculante do julgamento da ADI 3345, o TJMG, na Apelação Cível 1.0027.10.013587-3/002, afirmou que a Res. TSE n. 21.702/2004 era resultado do efeito transcendente daquela primeira decisão, confundindo portanto o conceito, porque o transporte não se faz para atos normativos, mas para recursos e ações pendentes de julgamento. $\mathrm{O}$ argumento ali usado está mais próximo da eficácia erga omnes do que da eficácia irradiante. Em outros, por fim, o próprio STF restringiu os efeitos do julgamento do RE 197.917 apenas às partes envolvidas: 1) Rcl 3051 Agr; 2) Rcl 3235 Agr; 3) Rcl 7786 Agr; 4) Rcl 5391 Agr; 5) Rcl 14.256 Agr; 6) Rcl 11.566 Agr; 7) Rcl 5871 Agr. No segundo período, mais longo, foram encontrados alguns julgamentos nos quais as eficácias transcendente/irradiante, erga omnes e até mesmo vinculante foram adotadas, expressa ou inexpressamente, no contexto da chamada abstrativização do controle difuso, a saber: 1) AGEPN n. 61942006, julgado em 07.12.2006 pelo TJMA, no qual se destacou a eficácia erga omnes de decisão do HC 82.959, no pressuposto da análise de tese em abstrato da matéria; 2) AGV (10000520020066126) em RO (100.005.2002.006612-6), julgado em 08.06.2006 pelo TJRO, no qual se reconheceu a eficácia erga omnes da decisão do HC 82.959, também no pressuposto da análise de tese em abstrato da matéria; 3) RAG 20070110943336 DF, julgado pela $1^{\text {a }}$ Turma Criminal no TJDF, em 24.04.2008, no qual a eficácia erga omnes e o princípio da abstrativização do controle difuso foram reconhecidos expressamente; 4) HC 79632008 MA, julgado pelo TJMA em 22.07.2008, no qual se reconheceu que a decisão do HC 82.959 transcendia o "limite das partes"; 5) EI 70018931261 RS, julgado pelo TJRS em 27.04.2007, no qual a abstrativização do controle difuso foi reconhecida expressamente; 6) RECAGRAV 3541526 PR 0354152-6, julgado pelo TJPR em 14.12.2006, no qual se reconheceu não apenas eficácia erga omnes à decisão do HC 82.959, como também vinculante, porém em nome da natureza do direito envolvido (direito fundamental à liberdade) e de uma alegada mutação constitucional; 7) APR 20060910014800 DF, julgado pela $1^{\text {a }}$ Turma Criminal do TJDF em 16.11.2006, no qual o voto vencedor primeiro minora a eficácia da decisão tomada em sede de controle difuso, para depois, por remissão ao parecer do MP, aderir à eficácia erga omnes e até mesmo vinculante da decisão paradigma. Em outros casos, julgados pelo STJ e por tribunais ordinários (por amostragem), a aplicação dos termos da decisão paradigmática do STF ocorreu com base (i) em argumentos apenas persuasivos, como, por exemplo, a autoridade do STF no controle difuso, o risco de reforma pelas vias recursais e os Revista de Direito Brasileira | São Paulo, SP | v. 16 | n. 7 | p. 324 - 345 | Jan./Abr. 2017 


\section{SÚMULAS ORDINÁRIAS VINCULANTES v. SÚMULAS VINCULANTES}

O presente tópico exige antes um acordo semântico quanto aos conceitos básicos de
modulação de efeitos, eficácia vinculantes, eficácia erga omnes e eficácia transcendente/irradiante, que podem ser assim resumidos para se evitar confusões terminológicas: 1) modulação de efeitos significa o poder do STF de estabelecer eficácia não retroativa ao pronunciar a inconstitucionalidade de determinado dispositivo/enunciado infraconstitucional, operando assim com a retroatividade média ou com eficácias ex nunc ou pro futuro, ao invés da tradicional eficácia ex tunc, ou para o passado. O STF deve proceder mediante um cálculo proporcional sobre as consequências menos gravosas do chamado princípio da nulidade, tanto no controle concentrado quanto no controle difuso; 2) eficácia transcendente/irradiante significa o transporte da tese jurídica vencedora de uma decisão (unânime ou não) tomada pelo STF em sede de controle difuso para outro recurso ou ação que tenha a mesma matéria (fática e jurídica) e esteja ainda pendente de julgamento, esta eficácia era necessária antes do advento do CPC, com o advento do CPC a teoria dos precedentes vinculantes cumpre a mesma função de forma

princípios da igualdade, da segurança jurídica e da celeridade, (ii) ou por simples remissão a ela: 1) Apelação Criminal n. 2006.37.00.003791-0/MA, julgada pela $4^{\text {a }}$ Turma do TRF-1; 2) Procs. ns. 2006.04.00.00000-7/SC, 2006.04.00.000008-7, 2003.71.03.002792-0, 2005.70.02.001696-7 e 2004.70.02.009280-1, julgados pelo TRF-4; 3) Apelação Criminal n. 2006.01.99.028025-1/AC, julgada em 05.06.2007 pela $4^{\text {a }}$ Turma do TRF-1; 4) ACR-MS 2004.60.02.000378-3 17766, ACR-SP 2003.61.19.008210-2 23625 e ACR-SP 2005.61.19.005641-0 27099, julgados pelo TRF-2; 5) HC-SP 2006.03.00.040656-9 24732, RVCR-SP 2003.03.00.028911-4 432 e 2003.60.02.003282-1 22139, HC-SP 2005.03.00.098799-9 23257, julgados pelo TRF-3; 6) HC 64073 SC 2006/0170981-7, HC 131772 SP 2009/0050964-3 e HC 53676 RJ 2006/0022596-1, julgados pela $5^{\text {a }}$ Turma do STJ. Em outros, ainda, houve expressa recusa em seguir a decisão paradigmática: 1) ACR-MS 2002.60.00.003229-0 14549, julgado pelo TRF-3; 2) ACR 2006.51.01.502883-5, julgado pelo TRF-2. Em conclusão, pontuou-se o seguinte: 1) a adoção de expedientes com eficácia vinculante autônoma (ADIs e SV) sucessivos das duas primeiras decisões paradigmáticas indica que elas eram desprovidas na origem desse caráter, de acordo com o próprio STF, já que do contrário elas teriam sido auto suficientes em gerar obediência; 2) logo, mesmo nas únicas 2 (duas) das decisões (TJPR-RECAGRAV 3541526 PR 0354152-6 e TJDF-APR 20060910014800 DF) em que houve fidelização à decisão paradigma por conta de expresso reconhecimento de seu caráter vinculante, dentro do período desprovido de eficácia vinculante por expediente complementar (SV n. 26), essa nota foi antes dada pelos próprios tribunais do que propriamente pelo STF; 3 ) a terceira decisão paradigma não precisou do mesmo recurso, porque o caso foi de simples transporte de decisões tomadas inicialmente em controle difuso para o juízo de admissibilidade do controle concentrado, portanto sem caráter vinculante, já que nesse caso não se limita ou se arrosta o controle difuso; 4) nos casos em que as eficácia transcendente/irradiante e erga omnes das decisões paradigma foram observadas, os tribunais adotaram sem reservas a tese jurídica vencedora, porém menos por conta de uma força vinculante do que propriamente em nome da universalização/abstração da tese jurídica vencedora e até mesmo da natureza do direito envolvido (direito fundamental à liberdade), embora o próprio STF tenha contribuído para minar a eficácia irradiante da primeira decisão paradigma, ao negar transcendência a ela nos julgamentos de várias Reclamações de Competência (Rcl 3051 Agr; Rcl 3235 Agr; Rcl 7786 Agr; Rcl 5391 Agr; Rcl 14.256 Agr; Rcl 11.566 Agr; Rcl 5871 Agr.); 5) em alguns casos a tese jurídica contida nas decisões paradigma foi aplicada por mera remissão ou por adoção das mesmas premissas nelas adotadas, sem questionamento ou contextualização, fato que caracteriza simples caráter persuasivo, também verificado com o emprego de argumentos como (i) a autoridade do STF no controle difuso, (ii) o risco de reforma pelas vias recursais e a (iii) incidência de princípios constitucionais, como os da segurança jurídica, da colegialidade, da igualdade, da segurança jurídica e da celeridade; 6) com isso, confirmam-se as hipóteses iniciais da pesquisa, porque: a) o próprio STF foi incapaz de indicar parâmetros seguros de incidência das eficácias transcendente/irradiante e erga omnes reconhecidas nas decisões paradigma, contribuindo ainda para miná-las em relação à primeira delas, ao negar-lhe transcendência em várias Reclamações de Competência; b) se as decisões paradigma fossem providas de eficácia vinculante desde a origem o STF não as teria aparelhado depois com decisões que ostentam tal eficácia de forma autônoma (ADI e SV), eficácia que sequer se aplica à terceira decisão paradigma, porque nela não se verifica limitação do controle difuso e da autotutela executiva. A pesquisa havia entendido que as hipóteses supra tornavam inconstitucionais as previsões dos arts. 525, § $1^{\circ}$, III, $\S 12$, e 535, III, $\S 5^{\circ}$, do NCPC, em torno da inexibilidade da sentença condenatória em cumprimento e do título executivo em face da Fazenda Pública quando fundados em dispositivo infraconstitucional reconhecido inconstitucional pelo STF em sede de controle difuso, de acordo com o princípio da razoabilidade/racionalidade, já que quebram a relação de meios e fins ao impor uma eficácia inexistente no plano constitucional.

Revista de Direito Brasileira | São Paulo, SP | v. 16 | n. 7 | p. 324 - 345 | Jan./Abr. 2017 
aperfeiçoada, justamente por terem os precedentes um caráter formal e material previsto na norma processual e implicarem na observância de todos os juízes e tribunais (e inclusive do próprio Tribunal) as decisões do plenário do STF em matéria de controle difuso; 3) eficácia erga omnes significa a obrigatoriedade de conhecimento da tese jurídica vencedora em uma decisão paradigmática do STF pela comunidade jurídica, tanto para casos ainda pendentes de julgamento como para as relações jurídicas materiais não judicializadas, ostentando assim caráter interno e externo; 4) eficácia vinculante significa a proibição de decisões em sentido contrário àquele estabelecido em determinada decisão paradigmática nos campos do controle difuso e da autotutela executiva.

Estabelecidos esses conceitos básicos, pode-se agora passar para a polêmica das súmulas ordinárias vinculantes, com reducionismo das súmulas vinculantes propriamente ditas ou com a maximização dos efeitos das súmulas ordinárias. Isso ocorre porque o art. 927, IV, do CPC determina que "os juízes e os tribunais observarão" "os enunciados das súmulas do Supremo Tribunal Federal em matéria constitucional" ("e do Superior Tribunal de Justiça em matéria infraconstitucional"), enquanto que o $\S 1^{\circ}$, VI, do art. 489 daquele mesmo Código prevê que nenhuma decisão judicial se considera fundamentada quando "deixar de seguir enunciado de súmula".

Se os deveres de observância e de seguimento das súmulas for entendido como proibição de decisões em sentido contrário à ratio decidendi estabelecida nas súmulas ordinárias ${ }^{37}$, teremos duas correntes possíveis, em linhas gerais: a) a primeira defende que elas serão tão vinculantes quanto às súmulas propriamente vinculantes; b) a segunda estabelece a distinção em função dos meios de impugnação, quórum qualificado da decisão para fins de formação da súmula vinculante e vinculatividade dos órgãos da administração pública, fenômenos que não ocorrem em relação as súmulas ordinárias e estão presentes nas súmulas vinculantes. Para a primeira visão, se não forem idênticas, as súmulas vinculantes e as súmulas ordinárias, essas deverão ser compreendidas como meras orientações persuasivas. ${ }^{38}$

É inegável a importância que o CPC deu às súmulas ordinárias, porque além das previsões supra, elas: 1) permitem a extinção sumária do processo por sentença de improcedência quando a tese da inicial contrariá-las (art. 332, I); 2) excepcionam a regra do duplo grau necessário, quanto ao diferimento dos efeitos da sentença condenatória, quando a sentença estiver

\footnotetext{
${ }^{37}$ Não estão em questão, aqui, as técnicas de distinguish e de overruling, previstas no art. $489, \S 1^{\circ}$, inc. VI do CPC, porque na primeira a decisão não confronta a ratio decidendi, limitando-se a excepcioná-la, enquanto que na segunda a adoção do entendimento contrário está tacitamente autorizada pelo próprio órgão editor da súmula que pode alterar o entendimento. É bom lembrar que as súmulas apenas externalizam a ratio decidendi dos precedentes que lhes deram origem e, portanto, estão a elas vinculadas (art. $926, \S 2^{\circ}$ ).

38 Para a explicitação das suas razões é bom colacionar trecho do trabalho: "Se é verdade dizer que todas as previsões supra relativas às súmulas ordinárias se aplicam com maior razão às súmulas vinculantes, assim como que as últimas previsões não se aplicam às súmulas ordinárias do próprio STF, será forçoso concluir que a ratio decidendi das súmulas ordinárias não é vinculante no sentido aqui descrito, pois do contrário elas usurparão o status normativo das súmulas propriamente vinculantes, num cenário desautorizado previamente pelo STF, ao converter nada menos do que 16 (dezesseis) de súmulas ordinárias em SVs (7 X 648; 37 X 339; 38 X 419; 39 X 647; 40 X 666; 41 X 670; 42 X 681; 43 X 685; 44 X 686; 45 X 721; 46 X 722; 48 X 661; 49 X 646; 50 X 669; 51 X 672; 52 X 724). Ora, se assim não for, de nada servirá a burocracia de edição das súmulas vinculantes e tampouco o trabalho que o STF se deu para praticar aquelas conversões. Portanto, a única conclusão coerente a que se chega é que as súmulas ordinárias não vinculam os juízes do mesmo modo que as súmulas propriamente vinculantes, a eles impondo outrossim um dever de contextualização nos casos em que elas tenham incidência, que se traduz grosso modo como dever de não ignorância da tese sumulada. Em outras palavras, o que os arts. $489, \S 1^{\circ}$, VI, e 927, IV, do NCPC proíbem são as decisões per incuriam, que ignoram a existência de súmulas ordinárias na matéria sob exame (SOUZA, Marcelo Alves Dias de. Do Precedente Judicial à Súmula Vinculante. Curitiba: Juruá, 2011, p.146-147), e não as decisões fundamentadas que eventualmente divirjam da ratio decidendi nelas contidas, inclusive porque esse é um meio legítimo de revisão e de atualização de entendimentos sumulados e que pode surgir especificamente no contexto do controle difuso, já que todas as matérias versadas em súmulas ordinárias do STF têm matiz constitucional."
} 
nelas fundada (art. 496, § $4^{\circ}, I$ ); 3 ) dispensam a caução no cumprimento provisório de sentença condenatória de obrigação de pagar quantia certa quando a sentença estiver nelas fundada (art. 521 , IV); 4) autorizam ao relator, de forma singular, a negar provimento a recurso a elas contrário ou a antecipar provimento a recurso que com elas esteja de acordo (art. 932, IV, "a", V, "a"); 5) pressupõem a priori a existência de repercussão geral do recurso extraordinário quando o acórdão recorrido estiver em desacordo com elas (art. 1035, $\S 3^{\circ}$, I).

Por outro lado, o CPC/2015 reservou para as súmulas propriamente vinculantes algumas consequências não estendidas às súmulas ordinárias, a saber: 1) autoriza a concessão liminar inaudita altera parte de tutela de evidência, sem necessidade de demonstração de perigo de dano ou de risco de ao resultado útil do processo, quando a tese da inicial estiver de acordo com elas (art. 311, II, mas não só, pois inclui também os casos repetitivos) ${ }^{39}$; 2) prevê reclamação de competência ao STF para garantir a observância de seus enunciados (art. 988, IV).

O dilema está posto, não há dúvida que negar eficácia vinculante aos enunciados de súmulas ordinárias, quando estes observarem os critérios materiais previstos nos arts. $926, \S 2^{\circ} \mathrm{e}$ $489, \S 1^{\circ}$, inc. V e VI, significaria quebrar a vinculatividade formal prevista no rol do art. 927 do CPC.

É preciso saber quais as vantagens deste discurso teórico e quais as suas consequências, visto que o dever de persuasão é menos exigente que o dever de vinculação.

\section{CONCLUSÃO}

Na parte relativa ao controle difuso o CPC não é auto evidente e exige o domínio de alguns conceitos chave do direito constitucional para ser aplicado de forma coerente, pois do contrário se observará um autêntico diálogo tardio de surdos e mudos entre processualistas e constitucionalistas, num confronto que vai além da mera conceituação, para afetar a sua aplicação prática, com notório prejuízo à dinâmica judicial.

A falta de diálogo prévio suficiente e amadurecido entre processualistas e constitucionalistas parece ter sido a causa desse problema, porque não se pode acreditar que previsões relativas a fortes teorias do direito constitucional tenham sido incluídas no novo código por força de uma arrogância unilateral, tanto mais quando elas são fruto de debates e polêmicas entre os próprios constitucionalistas e que por isso talvez devessem ter sido deixadas em seu locus, fora das previsões legislativas. Contudo, o Código não é um documento teórico e deve receber uma interpretação que lhe garanta a operabilidade.

Seja como for, espera-se que o presente trabalho forneça ferramentas conceituais para a aplicação coerente do CPC no campo do controle difuso, remediando assim o déficit de diálogo antes mencionado.

\section{REFERÊNCIAS}

ALEXY, Robert. Colisão e Ponderação como Problema Fundamental da Dogmática dos Direitos Fundamentais. Palestra proferida na Casa de Rui Barbosa, em 10.12.1998. Tradução de Gilmar Ferreira Mendes.

Epílogo a la Teoría de los Derechos Fundamentales. Revista Española de Derecho Constitucional. Madrid: Centro de Estudios Políticos y Constitucionales, n. 66, set/dez 2002.

\footnotetext{
${ }^{39} \mathrm{Um}$ dos autores deste texto entende que sendo os procedentes formalmente vinculantes a leitura dos dispositivos do CPC não pode ser fragmentada, sendo aplicável a premissa do art. 311, II, por exemplo, a todo o rol de precedentes previstos no art. 927, incisos. Cf.: ZANETI JR., Hermes. $O$ valor vinculante dos precedentes: teoria dos precedentes normativos formalmente vinculantes. $2^{\mathrm{a}}$ ed., rev. e ampl. Salvador: JusPodivm, 2016..
} 
. Teoría de los Derechos Fundamentales. Madrid: Centro de Estudios Políticos y Constitucionales, 2001.

ÁVILA, Humberto. Teoria dos Princípios. Da Definição à Aplicação dos Princípios Jurídicos. São Paulo: Malheiros, 2005.

CANAS, Vitalino. O Princípio da Proibição do Excesso na Constituição: arqueologia e aplicações. In: MIRANDA, Jorge (org.). Perspectivas Constitucionais. Nos 20 Anos da Constituição de 1976. Coimbra: Coimbra Editora, 1997, V. II.

CAPPELLETTI, Mauro. Il controlo giudiziario di costituzionalità delle leggi nel diritto comparato [1968], trad. para o português de Aroldo Plínio gonçalves, CAPPELLETTI, Mauro. $O$ controle de constitucionalidade de leis no direito comparado. trad. Aroldo Plínio Gonçalves; revisão José Carlos Barbosa Moreira. Porto Alegre: Sergio Antonio Fabris Editor, 1992.

CASTRO, Carlos Roberto de Siqueira. O Devido Processo Legal e a Razoabilidade das Leis na Nova Constituição do Brasil. Rio de Janeiro: Forense, 1989.

GARCÍA, Enrique Alonso. La Interpretacion de la Constitucion. Madrid: Centro de Estudios Constitucionales, 1984.

GIFIS, Steven H. Law Dictionary. New York: Barrońs, 2003.

JEVEAUX, Geovany Cardoso; PEPINO, Elsa. Comentários às Súmulas Vinculantes. Com pesquisa sobre a regra do art. 52, X, da CF. Rio de Janeiro: GZ, 2012.

MARINONI, Luiz Guilherme. Precedentes obrigatórios. 4a ed. São Paulo RT, 2016.

OLIVEIRA, Rafael Tomaz de. Decisão judicial e o conceito de princípio: a hermenêutica e a (in)determinação do direito. Porto Alegre: Livraria do Advogado, 2008.

SANDULLI, Aldo. Ecesso di Potere e Controllo di Proporzionalità. Profili Comparati. Rivista Trimestrale di Diritto Publico, Roma: Giuffrè Editore, 1995.

SOUZA, Marcelo Alves Dias de. Do Precedente Judicial à Súmula Vinculante. Curitiba: Juruá, 2011.

STRECK, Lenio. Art. 489. In.: STRECK, Lenio; NUNES, Dierle; CUNHA, Leonardo Carneiro da (orgs.). Comentários ao Código de Processo Civil. São Paulo: Saraiva, 2016.

. Verdade e consenso: Constituição, hermenêutica e teorias discursivas. $5^{\mathrm{a}}$ ed., revista,

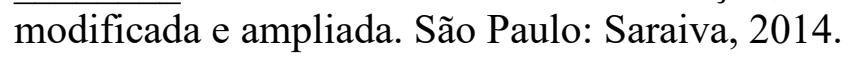

ZANETI JR., Hermes. O valor vinculante dos precedentes: teoria dos precedentes normativos formalmente vinculantes. $2^{\mathrm{a}}$ ed., rev. e ampl. Salvador: JusPodivm, 2016.

ZANETI JR., Hermes; PEREIRA, Carlos Frederico Bastos. Teoria da Decisão Judicial no Código de Processo Civil: Uma ponte entre Hermenêutica e Analítica?, Revista de Processo, n. 259, ano 41, p. 21-53. São Paulo: RT, 2016. 